\title{
MODIFICATION OF A LOCAL MACHINE THRESHING UNIT FOR THRESHING SUN FLOWER
}

\author{
Arafa, G. K.*
}

\section{ABSTRACT}

The objective of the present study is to test and evaluate the performance of Mabrouk type threshing machine for threshing sunflower heads (variety of vidok) after modification of the threshing drum and the cleaning unit. The machine performance was evaluated in terms of threshing efficiency, percentage of un-threshed seeds, percentage of seed losses, seeds purity, fan losses and losses behind sieves. The experimental work was carried out to investigate the effects of some engineering parameters of the machine threshing and cleaning units included threshing drum speeds of 300, 400, 500 and $600 \mathrm{rpm}$ (10.99, 14.65, 18.31 and $22.78 \mathrm{~m} / \mathrm{s}$ ), heads feeding rates of 300, 450, 600 and $750 \mathrm{~kg} / \mathrm{h}$, air velocity of $3.5,4.5$, and $5.5 \mathrm{~m} / \mathrm{s}$. suction fan, and sieve tilt angles of 2, 5 and 8 degree. The obtained results indicated that, considering the lower percentage of un-threshed and broken seeds and the higher threshing efficiency with acceptable machine capacity, the machine feed rate of $600 \mathrm{~kg} / \mathrm{h}$. and drum speed of $400 \mathrm{rpm}$ is recommended for threshing sunflower heads. Meanwhile, considering both seed purity and total seed losses, it can be said that the air velocity of $4.5 \mathrm{~m} / \mathrm{sec}$ with sieves tilt angle of 5 degree recorded proper seed purity of $98.5 \%$ with total seed losses of $0.42 \%$.

\section{INTRODUCTION}

unflower (Helianthus annuus L.) is one of the world's most important oilseed crops after soybeans for oil production in the world. Sunflower oil is considered to be of very high quality (Downey et al., 1989). (Rizvi et al.,1993) mentioned that the oil content of sunflower is $40 \%$, which is higher than any other oilseed crops he also compared. The performance of different threshing drums for sunflower threshing. The spike/peg teeth, rasp bar and mummer strip cylinder with their respective concaves were used.

* Senior Researcher, of Agr. Eng. Res. Inst., Agric. Res. Center. 
The study showed that the peg -type cylinder with a speed range of 400$500 \mathrm{~min}-1$ and concaves clearance rang from $25-30 \mathrm{~mm}$ can be used for a sunflower threshing unit . In Egypt, 1,129000 Mg of oils is consumed annually but till now Egypt produce only $153,000 \mathrm{Mg}$. This means that the oil production cover only about $13.55 \%$ of all our needs and the import approached about $86.45 \%(976,000 \mathrm{Mg})$. (Oilseed situation and outlook 2002) So, Egypt costs about 3220 million Egyptian pound (LE.) to cover this deficiency. Therefore, sunflower oilseed production occupies a key position in the overall economy of Egypt. Awady and El Sayed (1994) stated that when air stream is used for separation of product from its associated foreign materials, knowledge of terminal velocity of all particles is involved. For these reasons, terminal velocity has been used as an important aerodynamic characteristic of materials such applications as pneumatic conveying and separation from foreign materials. Ebaid (1995) concluded that for rice crop the highest purity of $98.8 \%$ and lowest fan losses of $0.13 \%$ were obtained at sieve tilt angle of 5 degrees, feeding rate of $2.2 \mathrm{t} / \mathrm{h}$, air speed $21 \mathrm{~m} / \mathrm{s}$ and $110 \times 30 \mathrm{~cm}^{2}$ sieve area. Losses behind sieve increased from 0.11 to $0.128 \%$ as the sieve tilt angle increased from 2 to 8 degrees at feed rate of $2.2 \mathrm{t} / \mathrm{h}$, air speed of $21 \mathrm{~m} / \mathrm{s}$ and sieve area of $110 \times 20 \mathrm{~cm}^{2}$. Anil et al. (1998) designed and developed a prototype threshing machine for sunflower seeds, using basic principles adopted for cereal threshers. Test results indicated that the optimal thresher performance was achieved at 9-13\% moisture content, $180 \mathrm{~kg} / \mathrm{h}$ feed rate and $500 \mathrm{rpm}$ cylinder speed. Helmy et al. (2000) tested the performance of the modified spike tooth drum used for sunflower threshing. He indelicate that the spike-tooth drum (D3) and the clearance ratio of 1.8 gave always better results of the performance evaluation for the modified thresher. Results also indicated that, for optimum performance the thresher's drum speed should be about $9.53 \mathrm{~m} / \mathrm{s}$ and the seeds moisture content ranged from $15.4 \%$ to $20.9 \%$. Also they found that the modified thresher gave better results of the total grain losses, grain damage and fuel consumption. Sudajan et al. (2002) studied the effect of drum type, drum speed and feed rate on sunflower threshing. They indicated that the grain damage increased with an increase in drum speed for all drums and feed rates. This increase was 
due to higher impact levels imparted to the crop during threshing at higher drum speeds. El-Sahrigi et al. (2002) studied the effect of using the general purpose combines to harvest, thresh and clean sunflower crop. They indicated that, the optimum forward speed for harvesting sunflower plant was $3.5 \mathrm{~km} / \mathrm{h}$ which gave the lowest total losses and maximum level of cleaning efficiency. Moisture content of $16 \%$ (w.b.) gave the lowest level of total losses and seed damage and achieved the highest level of cleaning and threshing efficiency while optimum cylinder speed and concave clearance were $500 \mathrm{rpm}$ and $2.2 \mathrm{~cm}$, respectively. El-Sayed et al. (2002) studied the effect of using the general purpose combine (Case International) to solve the problems appeared in manual or conventional harvesting of sunflower crop. They indicated that, by increasing forward speed from 1.7 to $2.7 \mathrm{~km} / \mathrm{h}$ the harvesting losses, unthreshed, total losses, and field capacity increased from 3.2, $1.95,8.75 \%, 1.1$ fed./h to $4.1,2.1,9.36 \%, 1.38$ fed./h, respectively. While the damaged losses, performance efficiency, decreased from $0.9,94.06$ $\%$, to $0.7,92.6 \%$, respectively. Khater (2000) indicated that threshing efficiency, cleaning efficiency and seed damage of sun flower increased by deceasing moisture content. Also he mentioned that the best moisture content is that given the lowest seed damage and seed losses, and the highest threshing and cleaning efficiency. Billy (2004) reported that, sunflower harvesting at high moisture content (18 to 20\%) normally results in higher yields, less bird damage, and less shattering or dropping of heads than when seeds are harvested at a lower moisture content. Sudajan et al.,(2002) conducted a study to compare the performance of the rasp bar drum and the peg tooth type in threshing sunflower heads . The results show that ,sunflower threshing capacity of a rasp bar drum was higher than peg tooth type (both with open and closed threshing drums ). The threshing efficiency was also found to be higher than 99\%.visible grain damage increased with an increase in threshing drum speed and feed rate of each type of threshing drum . Also ,the rasp bar drum showed reduction in the proportions of grain damage, grain losses and material other than grain separation compared to the peg tooth type In Egypt nowadays, there is no a local made threshing machine to thresh sunflower is available. Farmers in most areas thresh sunflower using a 
rice or wheat local threshing machines without any modification. However, the result obtained indicated that these threshers are not appropriate for threshing sunflower in terms of higher grain losses and lower cleaning efficiency. The main objective of this study is modifying the threshing and cleaning unit of the local made Mabrouk type threshing machine for threshing and cleaning sun flower heads. Also, to evaluate factors affecting the modified unit performance and efficiency in terms of threshing losses, machine capacity, seed purity and total seed cleaning losses.

\section{MATERIAL AND METHODS}

\section{1-Materials:}

\section{Tested crop:}

The commonly grown sunflower (variety vidok) was used for the experimental work. It was harvested by the traditional method. The moisture content of the seeds, heads and straw was determined by the oven-drying method at $105{ }^{\circ} \mathrm{C}$ for $3 \mathrm{hr}$. as recommended by (AOAC, 1990). The average initial moisture content of sunflower seeds was $16.05 \%$ w.b. Physical properties and characteristics of sunflower heads and seeds are summarized in Table (1). All the experimental tests were done during the harvesting season of 2012 at Manshiya location, Billbaes distract, Sharkia Governorate.

Table (1): Some physical properties of sunflower plants, heads and seeds of variety vidok.

\begin{tabular}{|l|l|}
\hline Moisture content, \% w.b. & 16.05 \\
\hline Seed Length, mm & 11.69 \\
\hline Seed Width, mm & 6.15 \\
\hline Seed Thickness, mm & 1.14 \\
\hline Seed Projected area, mm ${ }^{2}$ & 56.01 \\
\hline Seed Hardness, N & 34.11 \\
\hline Seeds Coefficient of friction on surface (Galvanized iron) & 0.66641 \\
\hline Seeds Terminal velocity, m/s & 5.86 \\
\hline Head diameter, mm & 214 \\
\hline Stem diameter, mm & 27 \\
\hline Seed yield/plant, g & 170.50 \\
\hline Mass of 1000 seeds, g & 83.5 \\
\hline
\end{tabular}




\section{Machine structure and specifications before modification:}

A local made axial flow threshing machine (Mabrouk type threshing machine) was used for the experimental work. The machine overall length, width, and height were 4150, 2080, and $2000 \mathrm{~mm}$, respectively. The machine consists of main frame, cover, threshing drum, concave, oscillating screen assembly, suction fan and ducts. It has one input counter shaft connected to the tractor P.T.O. The power transmission from the counter shaft to the threshing drum conducted through three Vbelts. Details of the machine structure are presented as follows:

\section{Cover and feeding opening:}

The machine has cover of overall length and width of 1260 and $800 \mathrm{~mm}$ respectively and a feeding opening of $1180 \times 500 \mathrm{~mm}$.

\section{Threshing drum :}

A peg tooth closed type threshing drum is installed for the threshing process. The drum dimensions are $750 \mathrm{~mm}$ for diameter and $1180 \mathrm{~mm}$ for length. The total number of threshing tooths are 120 arranged in four sets each set (30 tooth). The tooth dimensions are $240 \mathrm{~mm}$ long $30 \mathrm{~mm}$ wide and $6 \mathrm{~mm}$ thick. The drum concave was constructed from a perforated sheet metal with a round shape with $20 \mathrm{~mm}$ diameter perforation.

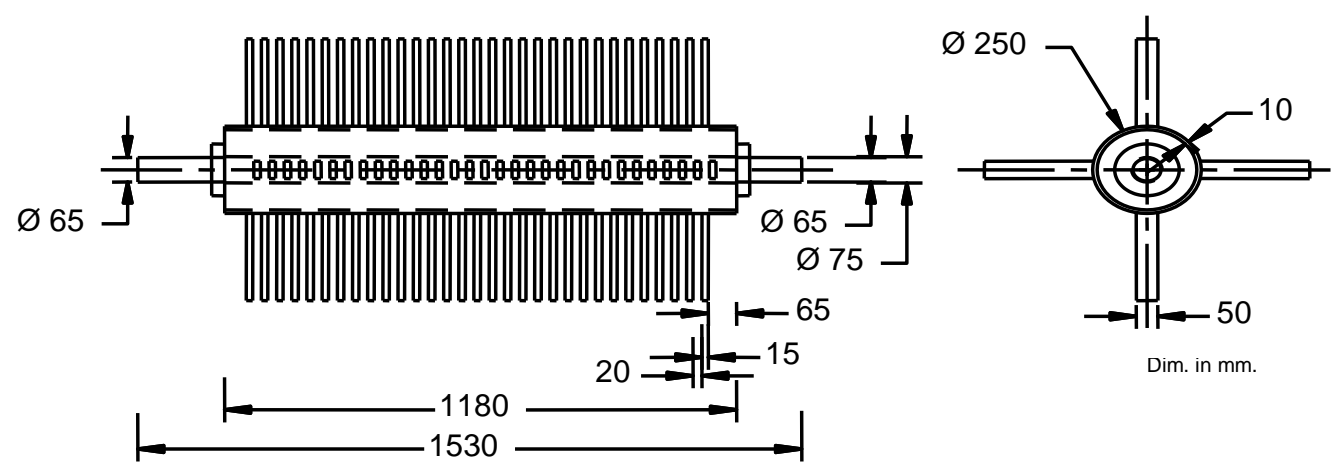

Fig. 1:A peg tooth type threshing drum before modification.

The concave clearance can be adjusted at the rang of 25 to $45 \mathrm{~cm}$. The length of the concave was $1180 \mathrm{~mm}$. for equivalent separation of seeds over the length of the threshing drum. 


\section{Cleaning screen:}

An oscillating screens made of metal sheet of $5 \mathrm{~mm}$ thickness installed in the machine cleaning and separation section. The sieves were consisted of upper and lower screens hanged on four link rods. The upper screen has two parts (solid and $15 \mathrm{~mm}$ diameter holes), while the lower screen is mounted $10 \mathrm{~cm}$ below parallel to the upper screen It was consists of three parts (solid - $1 \mathrm{~mm}$ diameter holes and $9 \mathrm{~mm}$ diameter holes).

\section{Suction fan and ducts:}

The suction fan consists of six radial blades. The fan housing has two suction ducts, the front is to pick large straw pieces over the upper sieve and the rear is to pick up chaff and light impurities from the lower screen.

\section{Machine modifications to suit threshing of sunflower seeds:}

\section{Drum cover}

The drum cover was modified to be with five adjustable spiral louvers which can be set to change the movement of the heads along the axis of the threshing drum, and the angle of louvers is $15-20^{\circ}$. It has overall length and width of 1260 and $800 \mathrm{~mm}$ respectively and the feeding opening was enlarged to be $250 \times 500 \mathrm{~mm}$. to suit the feeding of sunflower heads without any obstruction.

Threshing drum: As obtained from the preliminary experiments. Due to the lower capacity of the peg tooth drum in comparison with the rasp bar drum and also the higher percentages of grain damage (4-5\%), grain losses (7-8\%) and the lower cleaning efficiency $85-90 \%$ of this type. The peg tooth closed type threshing drum was replaced by a rasp bar type, closed threshing drum having four equidistant stationary bars built on the periphery of the drum in a parallel orientation as shown in fig. (2).The rasp bar dimensions are $1180 \mathrm{~mm}$ long $50 \mathrm{~mm}$ wide and $15 \mathrm{~mm}$ thick. The drum concave was constructed from a perforated sheet metal with elliptical holes of $15 \mathrm{~mm}$ by $60 \mathrm{~mm}$. The distance between adjacent holes was $11 \mathrm{~mm}$ and between the hole axes was $22 \mathrm{~mm}$. Meanwhile the concave clearance was fixed at $35 \mathrm{~mm}$ which proved satisfied for threshing sunflower seeds as obtained from the preliminary tests. On the same time the upper oscillated screen of the original machine was left without changes. While the lower screen parts was modifitied to be (solid, I mm diameter holes and $13 \mathrm{~mm}$ diameter holes screen). The air 
velocity of the suction fan was adjusted to different levels based on the results of terminal velocity tests of sunflower seeds at $16.05 \%$ w.b. moisture content.
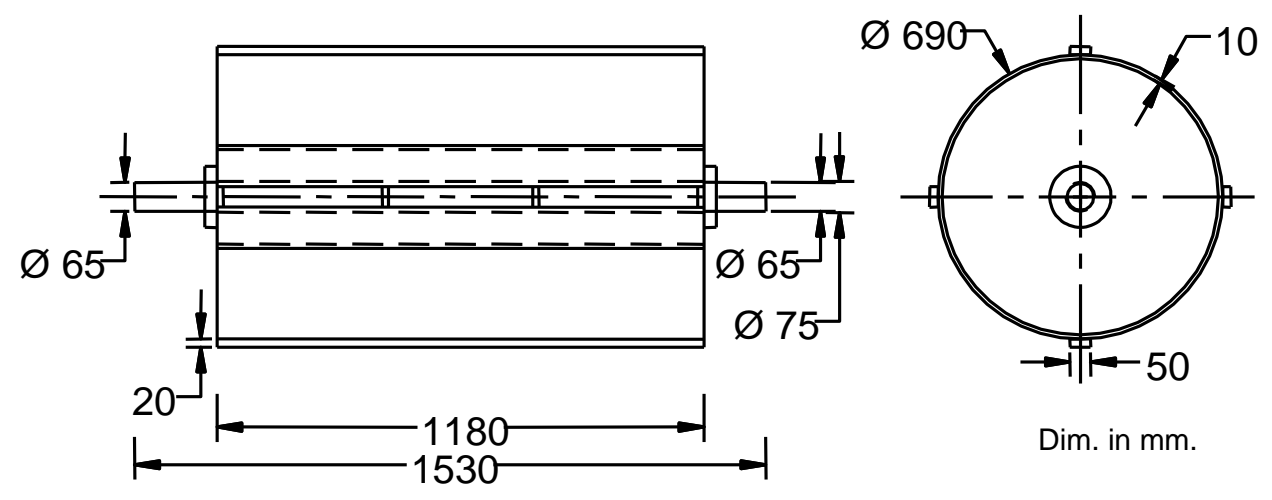

Dim. in $\mathrm{mm}$.

Fig. 2: A rasp bar type threshing drum after modification.

\section{Instrumentation}

Tachometer.

A Japanese made tachometer was used to measure the rotation speed of the threshing drum with a measuring range. of 100 to $5000 \mathrm{rpm}$, and accuracy of \pm 1 .

\section{Anemometer.}

A hot wire anemometer made in Japan by SATAKE CO was used for measuring air velocity. The reading of the anemometer ranged from 0 to $50 \mathrm{~m} / \mathrm{s}$ with accuracy of \pm 0.5 .

\section{Digital dial caliper.}

Dimensions of sunflower seeds were determined considering the three axes $\mathrm{xx}$, yy, and $\mathrm{zz}$. A digital caliper reading up to $15 \mathrm{~cm}$ was used. Its accuracy is $0.05 \mathrm{~mm}$.

\section{Electronic balance.}

An electronic balance model LB-25x (made in Japan) was used for weighing samples before and after cleaning. Its scale ranged from 0 to 5 $\mathrm{kg}$ max., with accuracy of $0.2 \mathrm{~g}$.

\section{Seed moisture content.}

Seeds moisture content in wet basis was measured by taking random samples in electric oven at $105{ }^{\circ} \mathrm{C}$ for three hours according to AOAC (1990). The moisture content was calculated using the following equation: 


$$
\text { Moisture content }(\% \mathbf{w} . \mathbf{b})=\frac{M_{w}-M_{d}}{M_{w}} \times 100
$$

Where: $\mathrm{Mw}=$ Mass of wet samples, $(\mathrm{g})$.

$\mathrm{Md}=$ Mass of dry samples, $(\mathrm{g})$;

\section{seeds terminal velocity:}

Terminal velocity appartue consists of $0.25 \mathrm{~kW}$, centrifugal fan connected to $70 \mathrm{~cm}$ PVC horizontal tube and $60 \mathrm{~cm}$ vertical transparent glass tube and a hot wire anemometer was used for determination of seeds terminal velocity.

\section{Experimental Treatments:}

The following parameters were considered during the threshing process to show their effect on threshing efficiency of the modified machine:

1-Drum speed: four different drum speeds were tested 300, 400, 500 and $600 \mathrm{rpm}(10.99,14.65,18.31$ and $22.78 \mathrm{~m} / \mathrm{sec}$.)

2-Head feed rate: four different feed rates were tested 300, 450, 600 and $750 \mathrm{~kg} / \mathrm{h}$.

3-Air speed: three different air speeds were tested 3.5, 4.5, and $5.5 \mathrm{~m} / \mathrm{s}$.

4-Sieve tilt angle: three different angles were tested 2, 5 and 8 degrees.

\section{Experimental measurements:}

\section{Measurements of the threshing process:}

\section{Percentage of unthreshed grain:}

$\%$ Unthreshed seeds $=\frac{\text { Weight of unthreashed seeds }}{\text { Seed production }+ \text { Losses }} \times 100$--------- (2) $\underline{\text { seeds }}$

\section{damage:}

The damaged seeds were sorted manually and weighed. The percentages of seeds-damage were calculated as related to the total weight of sample.

\section{Threshing efficiency.}

The threshing efficiency was calculated using the following relation:-

$$
E t h=\frac{M s-M t h}{M s}
$$

where: $E t h=$ threshing efficiency, \%

$$
\begin{aligned}
M t h & =\text { mass of un-threshed seed }, \mathrm{kg} \\
M s & =\text { total seed mass, } \mathrm{kg}
\end{aligned}
$$




\section{Total threshing losses.}

The threshing losses were calculated using the following relation:

$$
\text { Threshing losses, } \%=\frac{\text { Massof seeds loss } \quad(\mathrm{kg})}{\text { Total massof seeds } \quad(\mathrm{kg})} \times 100-\text {-- (4) }
$$

\section{Measurements of the cleaning process:}

Seeds purity: Seed ratio after removing the impurities (on mass basis) was calculated as follows.

$$
\text { Purity } \%=\frac{\text { mass of clean sample }}{\text { mass of sample before cleaning }} \times 100 \text {----------- }
$$

Fan losses: mass of seeds lost with the fan outlet was calculated as follows:-

$$
\text { Fan losses } \%=\frac{\text { seeds collected from fan outlet }}{\text { total seeds output }} \times 100 \text {----- (6) }
$$

Losses behind sieves: mass of seeds lost behind sieve was calculated as follows:

Losses behind sieves $\%=\frac{\text { seeds collected behind sieves }}{\text { total seeds output }} \times 100--(7)$

\section{RESULTS AND DISCUSSION}

\section{A) Threshing experiments:}

\section{1) Effect of drum speed and feed rate on percentage of unthreshed} seeds :

Fig, (3-a) illustrates the percentage of unthreshed seeds as related to feed rate of sunflower heads at different speeds of the rasp bar drum. As shown in the fig. (3-a) the percentage of unthreashed seeds increased with the increase of heads feed rate. While it was decreased with the increase of drum speed. At the minimum feed rate of $300 \mathrm{~kg} / \mathrm{h}$. the percentage of unthreashed seeds decreased from 0.19 to $0.038 \%$ with the increase of drum speed from 300 to $600 \mathrm{rpm}$. While at the maximum feed rate of $750 \mathrm{~kg} / \mathrm{h}$. it was decreased from 1.89 to $0.95 \%$. In general the percentage of unthreshed seeds was ranged from 0.038 to $1.89 \%$. 


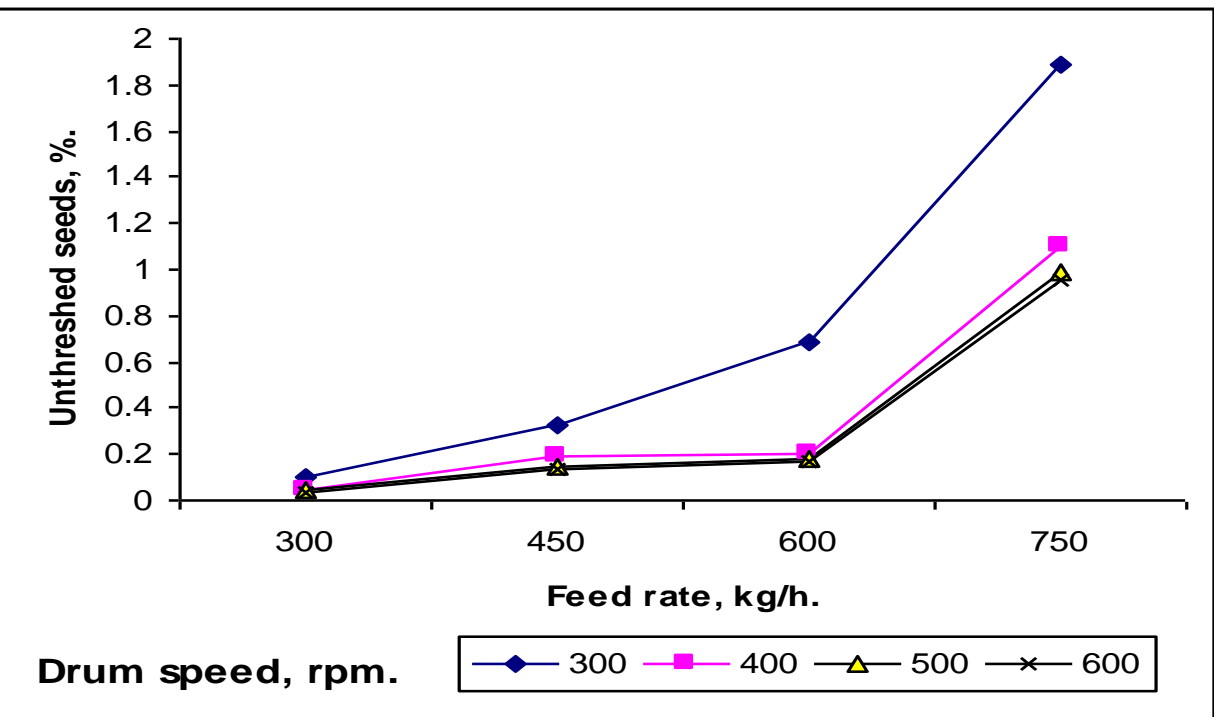

Fig. 3-a: Relationship between feeding rate and unthreshed grain.

\section{2) Effect of drum speed and feed rate on percentage of damaged seeds :}

Fig, (3-b) presents the relationship between the percentage of broken seeds and the heads feed rate at different drum speeds. As shown in the figure, the seed damage increased with the increase of both drum speed and heads feed rate and it was ranged from 0.16 to $2.89 \%$.

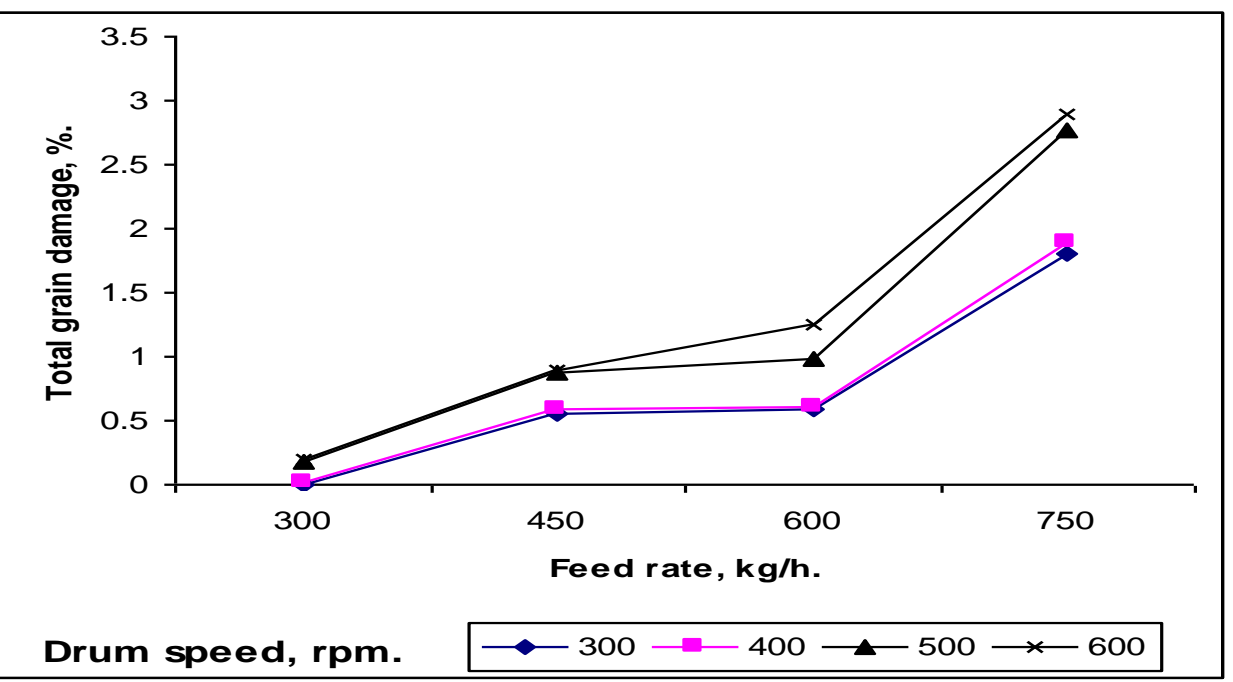

Fig. 3-b: Relationship between feeding rate and total grain damage. 
However it was clear that the difference between the percentages of seed damage was very close at the drum speeds of 400 and $500 \mathrm{rpm}$. And also at feed rats of 450 and $600 \mathrm{~kg} / \mathrm{h}$. (less than $2 \%$ ). While it was increased over $2 \%$ at the feed rate of $750 \mathrm{~kg} / \mathrm{h}$. The above mentioned results revealed that, the higher feed rate and drum speed increased the seed damage due to the impact imparted to the crop during the threshing process. However the recommended parameters are those at which the visible seeds damage should be within the range of less than $2 \%$ as recommended by (Vejasit,1991) to maintain better storage qualities. This means that drum speed of $400 \mathrm{rpm}$ and feed rate of $600 \mathrm{~kg} / \mathrm{h}$. were found to be suitable to obtain reasonable level of damaged seeds.

\section{Effect of drum speed and feed rate on percentage of Seed losses}

Fig, (3-c) shows the relationship between heads feeding rate and the percentage of seed losses at different drum speeds. As shown in the figure seeds losses increased by increasing feed rate, from 300 to 750 $\mathrm{kg} / \mathrm{h}$ at all level of drum speeds while, the recorded seed losses were relatively close at 300 and $400 \mathrm{rpm}$, while it was higher at the levels over $400 \mathrm{rpm}$. The recorded losses of seeds were 0.09, 0.19, 0.21 and $0.55 \%$ at feed rates of $300,450,600$ and $750 \mathrm{~kg} / \mathrm{h}$ respectively and the drum speed of $400 \mathrm{rpm}$.

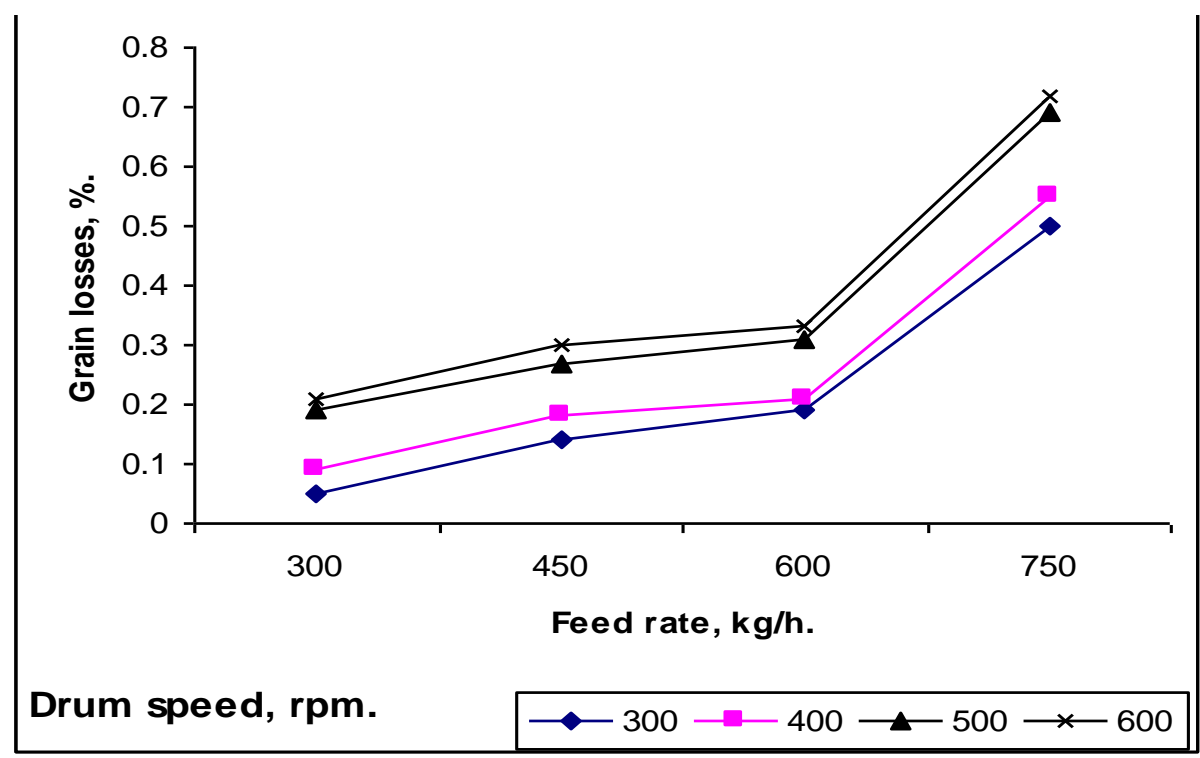

Fig. 3-c: Relationship between feeding rate and grain losses. 
Fig. 3-d: Relationship between feeding rate and threshing efficiency.The results indicated that the threshing efficiency was within the range of 90.11 to $99.8 \%$. Also, the threshing efficiency increased with the increase of drum speed while it was decreased with the increase of feed rate. In general the feed rate of 450 and $600 \mathrm{~kg} / \mathrm{h}$. at drum speed of 400 showed very narrow values of threshing efficiency ranged from 98.21 to 98. $95 \%$. The above mentioned results revealed that, considering the lower percentage of unthreshed and broken seeds and the higher threshing efficiency with acceptable machine capacity it can be said that the machine feed rate of $600 \mathrm{~kg} / \mathrm{h}$. and drum speed of $400 \mathrm{rpm}$ is recommended for machine of threshing sunflower heads.

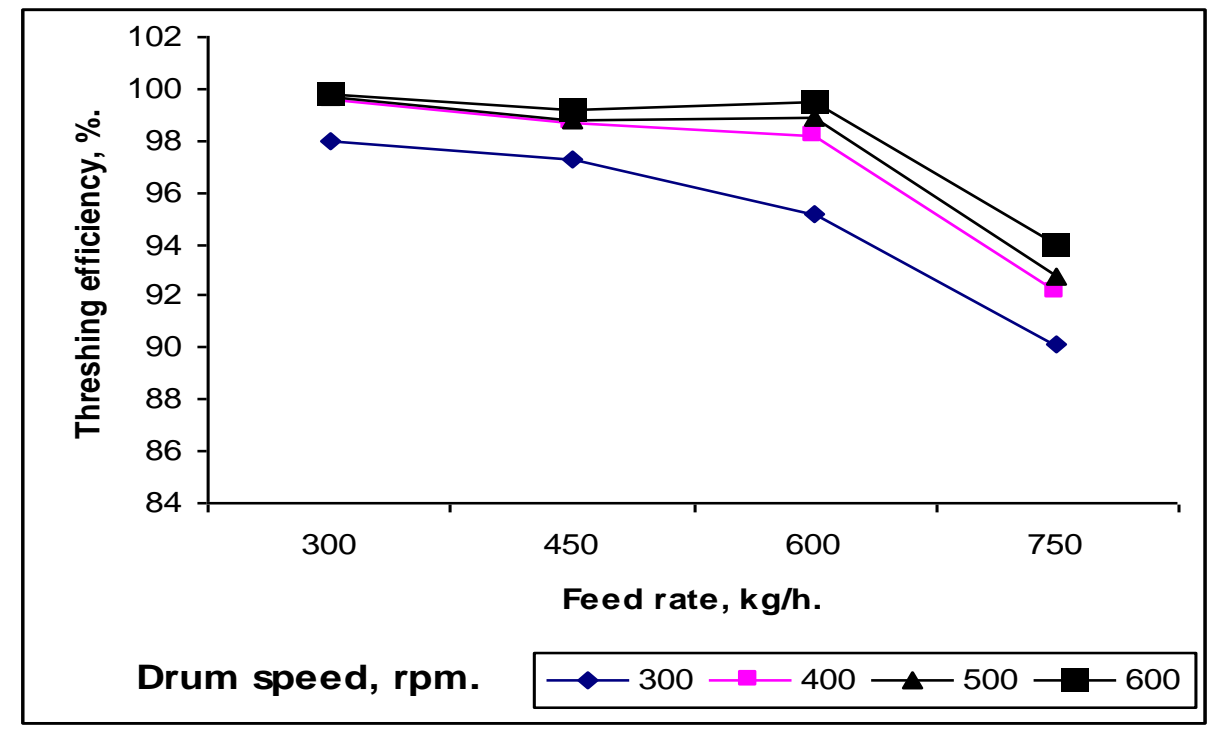

Fig. 3-d: Relationship between feeding rate and threshing efficiency. B)Cleaning Experiments:

All the experimental work for the cleaning process was conducted at the optimum operational condition of the threshing unit of the machine. This condition included a drum speed of $400 \mathrm{rpm}$ and a feed rate of $600 \mathrm{~kg} / \mathrm{h}$.

\section{Seed Purity .}

Fig. 4-a and 4-b illustrates the effect of air velocity on the purity of the threshed seeds at different tilt angles of the cleaning sieves. 


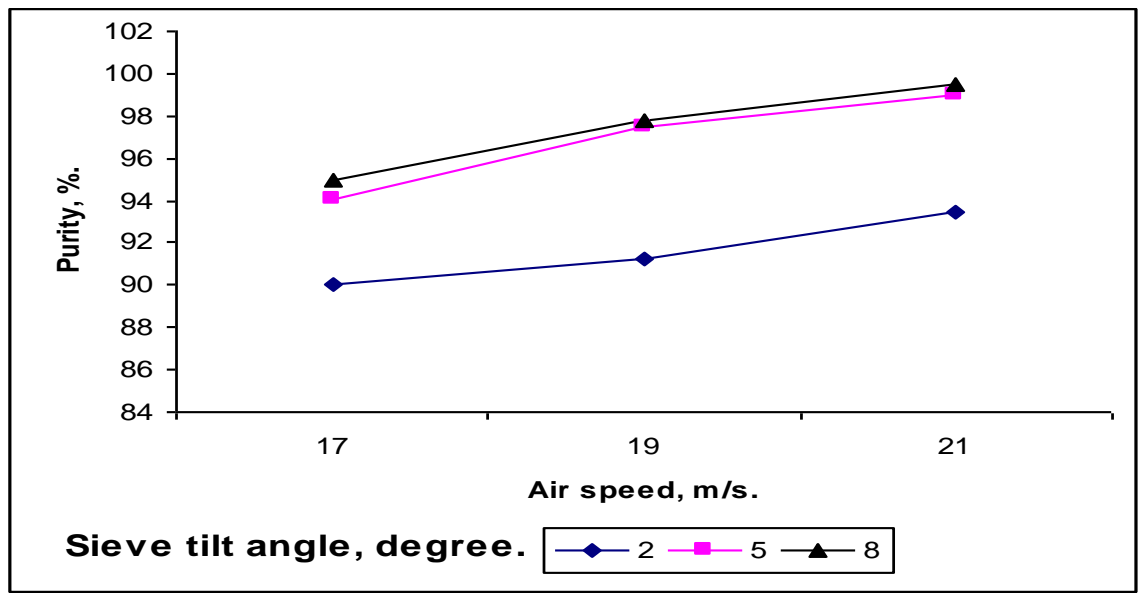

Fig.4-a: Relationship between air speed and purity.

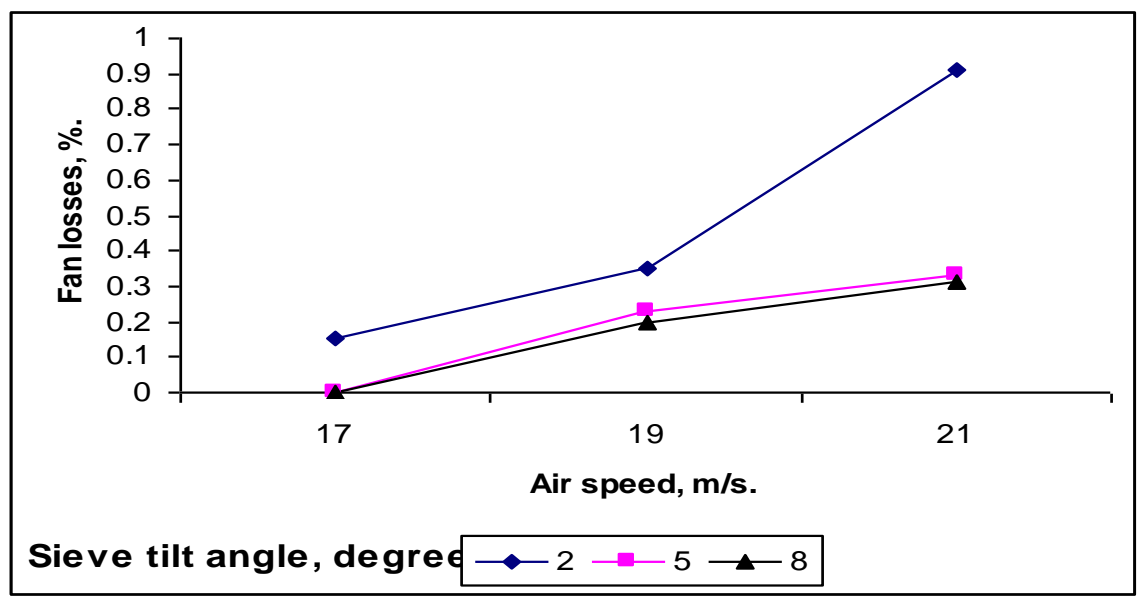

Fig4-b: Relationship between air speed and fan losses.

As shown in the figure, the seed purity was increased with increasing of both the air velocity and the sieves tilt angle.. As, the air velocity increased from 3.5 to $5.5 \mathrm{~m} / \mathrm{s}$. the seed purity increased from 90 to 93.5 $\%$, from 94.1 to $98.7 \%$ and from 95 to $98.9 \%$ at sieve tilt angles of 2, 5 and 8 degree respectively. This means that at higher air velocity the impurities are thrown out of the seeds. Also as the sieve tilt angle increased the chance for impurities to separate out of the seeds is increased and the seed purity increased.

\section{Total seed losses of the cleaning unit.}

Table (2) presents the relationship between total seed losses including (fan loses + losses behind sieves) as related to air velocity at different sieve tilt angles. As shown in the table, the total seed losses of the cleaning unit increased with the increase of air velocity and also with the 
increase of sieve tilt angle. As the air velocity increased from 3.5 to 5.5 $\mathrm{m} / \mathrm{s}$, the total seed losses increased from 0,35 to $0.49 \%$, from 0.39 to $0.52 \%$ and from 0.44 to $0.69 \%$ at sieve tilt angles of 2, 5, and 8 degree respectively. In general considering both seed purity and total seed losses, it can be said that the air velocity of $4.5 \mathrm{~m} / \mathrm{sec}$ with tilt angle of 5 degree recorded proper seed purity of $98.5 \%$ with total seed losses of $0.42 \%$ in comparison with other studied combinations.

Table (2): Effect of different sieve tilt angle and air velocity on total seed losses (fan losses + losses behind sieves).

\begin{tabular}{|c|c|c|c|c|}
\hline $\begin{array}{c}\text { Air } \\
\text { velocity } \\
\text { m/sec. }\end{array}$ & $\begin{array}{c}\text { Sieve tilt angle } \\
\text { Degree }\end{array}$ & $\begin{array}{c}\text { Fan } \\
\text { losses } \\
\%\end{array}$ & $\begin{array}{c}\text { Losses behind } \\
\text { sieves } \\
\%\end{array}$ & $\begin{array}{c}\text { Total seed } \\
\text { losses } \\
\%\end{array}$ \\
\hline \multirow{3}{*}{3.5} & 2 & 0.24 & 0.11 & 0.35 \\
\cline { 2 - 5 } & 5 & 0.23 & 0.16 & 0.39 \\
\cline { 2 - 5 } & 8 & 0.15 & 0.29 & 0.44 \\
\hline \multirow{3}{*}{4.5} & 2 & 0.27 & 0.13 & 0.40 \\
\cline { 2 - 5 } & 5 & 0.25 & 0.17 & 0.42 \\
\hline \multirow{3}{*}{5.5} & 8 & 0.22 & 0.32 & 0.54 \\
\cline { 2 - 5 } & 2 & 0.35 & 0.14 & 0.49 \\
\cline { 2 - 5 } & 5 & 0.33 & 0.19 & 0.52 \\
\hline
\end{tabular}

\section{COUNCLOUSION}

A modification for the threshing drum and the cleaning unit was carried out for (Mabrouk type) threshing machine to be used for threshing sun flower heads. The performance of the machine threshing and cleaning units was conducted under four different threshing drum speeds 300, 400, 500 and $600 \mathrm{rpm}(10.99,14.65,18.31$ and $22.78 \mathrm{~m} / \mathrm{s})$, four different feeding rates $300,450,600$ and $750 \mathrm{~kg} / \mathrm{h}$,three different air speeds of the suction fan $3.5,4.5$, and $5.5 \mathrm{~m} / \mathrm{s}$., and three different sieves tilt angles 2 , 5 and 8 degrees. The obtained results indicated that, considering the lower percentage of un-threshed and broken seeds and the higher threshing efficiency with acceptable machine capacity, the machine feed rate of $600 \mathrm{~kg} / \mathrm{h}$. and drum speed of $400 \mathrm{rpm}$ are recommended for machine operation of the threshing unit. Meanwhile, considering both seed purity and total seed losses during the cleaning process, it can be said that the air velocity of $4.5 \mathrm{~m} / \mathrm{sec}$ with sieves tilt angle of 5 degree recorded the most proper seed purity of $98.5 \%$ with the lowest total seed losses of $0.42 \%$. 


\section{REFERENCES}

Anil J; Guruswamy T; Desai SR; Basavaraj T; Joshi A (1998). Effect of cylinder speed and feed rate on the performance of thresher. Journal of Agricultural Sciences, 4, 1120-1123.

AOAC, Association of Official Analytical Chemists (1990). "Official Methods of Analysis" $15^{\text {th }}$ ed. Association of Official Analytical Chemists, Washington D.C., U.S.A.

Awady, M. N., and A. S. Sayed, (1994). Separation of peanut seeds by air stream. MJAE., 11 (1) : 137-147.

Billy, E. W. (2004). Sunflower production guide for west central texas. PP: (1-15).

Downey R K; Robbelen G; Ashri A (1989). Oil Crop of the World, their Breeding and Utilization. McGrawHill Publishing Company, New York.

Ebaid, M. T.(1995). Optimization of air screen cleaning system for threshers. M. Sc. Th., Fac. of Agric., Ain Shams Univ., Egypt.:7075.

El-Sahrigi, A. F; H. N. Adel-Mageed; M. A. EL-Saadany and M. M. Hassan (2002). Field performance of combines in harvesting sunflower crop. J. Agric. Sci., Mansoura Univ., 27(4):2553- 2572.

El-Sayed,G. H.; M. A. EL-Ataar and E. M. Arif (2002).Mechanical harvesting of sunflower using the general purpose combine. The 10 th conference of the Misr of Ag. Eng., 16-17 October: 155-172.

Helmy. M. A; I. S. Yousef and M. A. Badawy (2000). Performance Evaluation of some sunflower threshers. Egypt. Agric Res. 78(2): 959974.

Khater, A. E. A. (2000). Mechanization of sunflower threshing. M. Sc. Thesis. Agric. Eng., Mansoura Univ.

Rizvi S H A; Amjad N; Shaheen M A (1993). Comparative performance of different threshing drums for sunflower. Agricultural Mechanization in Asia, Africa and Latin America, 24(1), 23-27.

Sudajan, S. ;V.M. Salokhe and K. Triratanasirichai (2002). Effect of Type of Drum, Drum Speed and Feed Rate on Sunflower Threshing. Biosystems Engineering, 83 (4):413-421. 
Vejasit A. (1991). A comparison between peg tooth and rasp bar cylinders for soybean threshing using axial flow thresher. M.Sc thesis . Khon kaen univ. Khon kaen Thailand (unpublished).

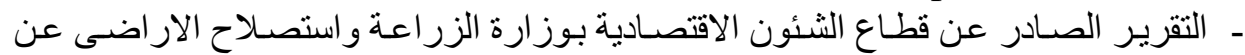

موقف البذور الزينية ومستقبلها (Oilseed situation and outlook2002) الملخص العربى

تعديل وحدة الدراس لآلة دراس محلية الصنع لاراس عباد الشمس

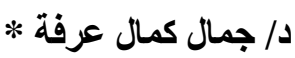

يعتبر عباد الثمس أحد المحاصيل الزر اعية فى مصر التى يمكن إستخدامه للتغلب على مشكئ مشكلة

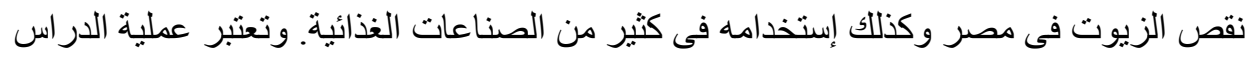

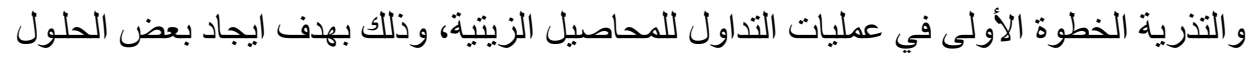

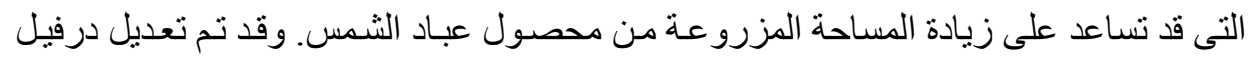

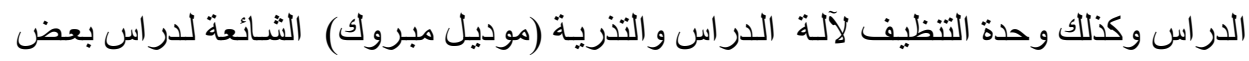

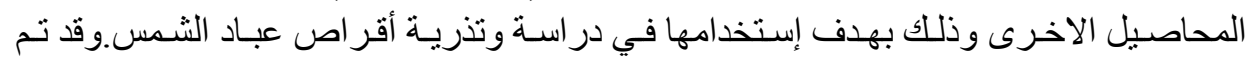

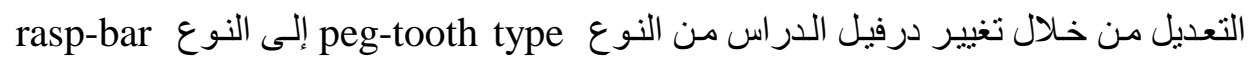

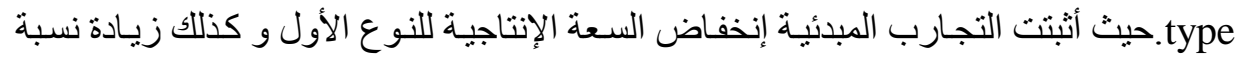

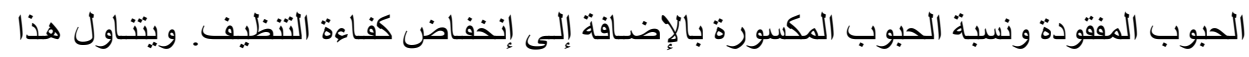

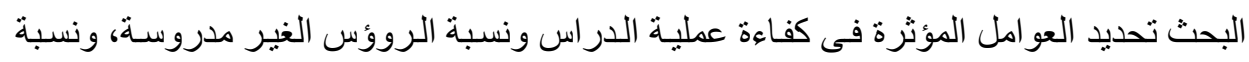

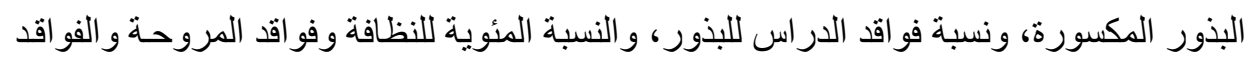

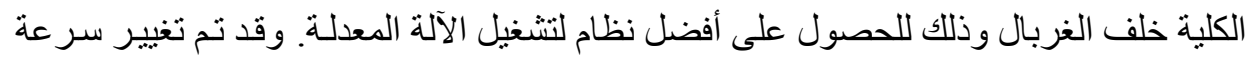

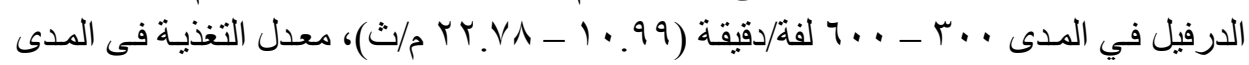

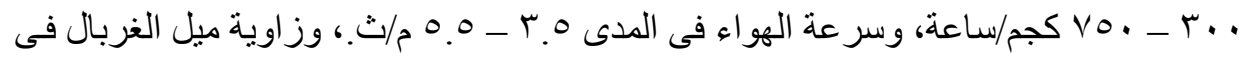

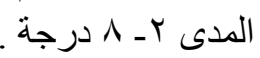

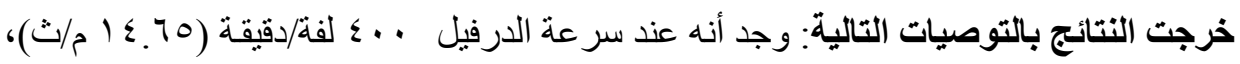

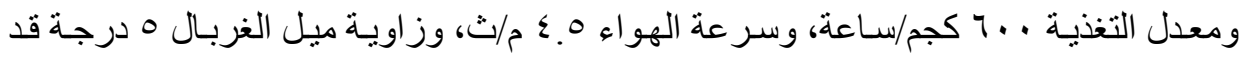

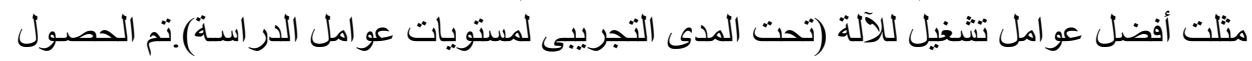

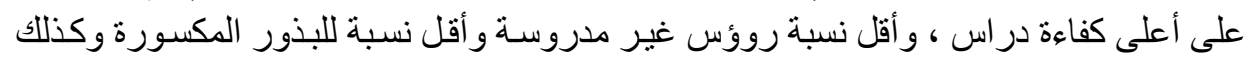

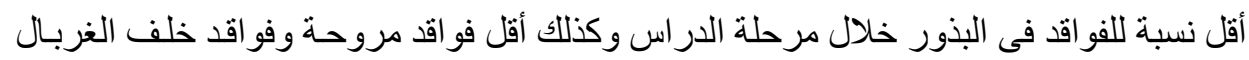

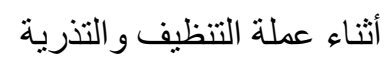

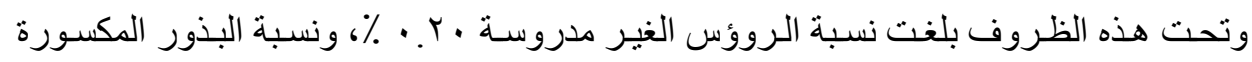

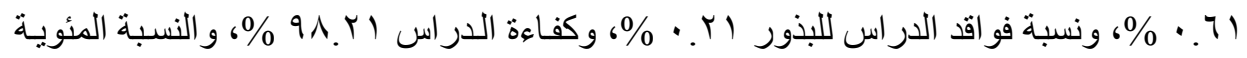

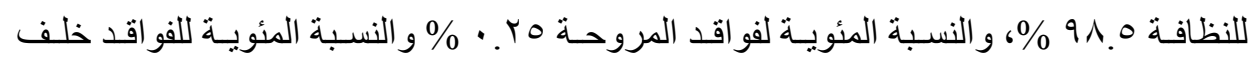

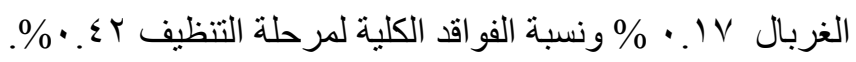

* باحث أول ـ معهد بحوث الهندسة الزراعية ـ مركز البحوث الزراعية ـ الجيزة ـ مصر. 